\title{
Position of Fatwa in The Constitution: A Legal Analysis
}

\author{
Mohd Kamel Mat Salleh ${ }^{1 *}$, Adibah Bahori ${ }^{2}$ and Mohamad Azhan Yahya ${ }^{3}$ \\ ${ }^{1}$ Academy of Contemporary Islamic Studies, Universiti Teknologi MARA Cawangan Negeri Sembilan, Kampus \\ Seremban, 70300 Seremban, Negeri Sembilan, Malaysia \\ ${ }^{2}$ Academy of Contemporary Islamic Studies, Universiti Teknologi MARA Cawangan Negeri Sembilan, Kampus \\ Rembau, 71300 Rembau, Negeri Sembilan, Malaysia \\ ${ }^{3}$ Faculty of Law Universiti Kebangsaan Malaysia, 43600, UKM Bangi, Selangor Darul Ehsan, Malaysia
}

\begin{abstract}
Fatwas in Malaysia seems to be existing without legal power and value since they are not mentioned literally in the Federal Constitution. Accordingly, there has been a perception of fatwa institutions issuing fatwas without legal authority to bind Muslims to certain legal decisions and views. Hence, this study is to clarify that fatwas are valid and recognized as part of the legal reference in Malaysia. More importantly, this paper refutes the claim that fatwa is unconstitutional in terms of its legal position. Additionally, this study intends to clarify that the philosophy of federalism practiced in Malaysia is solid evidence that fatwas are indeed an authoritative source of law in Malaysia. This study is conducted qualitatively using document analysis instruments with reference to the Federal Constitution and legal provisions practiced in Malaysia. Investigation of this study found that fatwa and its institutions in the country are valid according to Malaysian law. However, they are not mentioned literally in the Constitution, particularly fatwa authority that involves state jurisdiction in Islamic affairs. Moreover, this paper is highly significant to highlight the validity of fatwa from the Constitution perspective and further support the authority and credibility of its institutions according to Malaysian law.
\end{abstract}

Keywords: Civil law, fatwa, federal constitution, Shariah law

ARTICLE INFO

Article history:

Received: 02 April 2021

Accepted: 25 June 2021

Published: 05 November 2021

DOI: https://doi.org/10.47836/pjssh.29.4.04

$\overline{\text { E-mail addresses: }}$

mohdkamel@uitm.edu.my (Mohd Kamel Mat Salleh)

adibahbahori@uitm.edu.my (Adibah Bahori)

azhan@ukm.edu.my (Mohamad Azhan Yahya)

* Corresponding author

\section{INTRODUCTION}

The Malaysian Constitution recognizes Islam as the religion of the Federation and allows followers of other religions to practice their respective religions. This provision makes Islam dominant in the legal landscape of the country compared to other religions. In Article 74 (2) and 
Item 1, State List, Ninth Schedule, Federal Constitution provides that all matters relating to Islam and Islamic law are under the jurisdiction of the state. The question is whether the institution of fatwa and the existence of Mufti Departments in Malaysia is considered constitutional?

In Malaysia, the role of fatwa and muftis are not limited to resolving issues pertaining to Islamic law. However, they also deliver an interpretation of Islamic hukum and practices pursuant to the Government policy. Thus, the fatwa also represents the government on matters or disputes related to Islamic practice. In Malaysia, two fatwa institutions are established under national law, at the national and state levels. For a practical implementation of both fatwa institutions, the federal government has established the Fatwa Committee of the National Council for Islamic Religious Affairs Malaysia (MKI Fatwa Committee) established in early 1970 under Regulation 11, Regulations of the National Council for Islamic Religious Affairs Malaysia (Department of Islamic Development Malaysia [JAKIM], (2013). While at the state level, the State Fatwa Committee is established under the provisions of each Act / Enactment of the Administration of Islamic Religion of the States. Decisions from the muzakarah issued by the MKI Fatwa Committee cover national interests in various fields such as faith, Shariah, muamalat, law, medicine, pharmaceutical, biotechnology, including political and state issues (JAKIM, 2018).

The National Muzakarah Committee under the Department of Islamic
Development Malaysia (JAKIM) is an organization that issues legal views at the federal level. As provided in Rule 14 of the MKI Rules, this Committee has to consider, decide and issue fatwas on any matter relating to the religion of Islam referred to it by the Conference of Rulers (Majlis Raja-Raja). The Committee will submit its opinion to the MKI, then submit its recommendations to the Conference of Rulers. It shows that the Conference of Rulers directly refers to this Committee as the highest monarchical institution in Malaysia. The Federal Constitution itself recognizes and protects the unique position of the Conference of Rulers as provided in the Article.

While at the state level, the establishment of the State Fatwa Committee and its functions are found in every Act/Enactment of the Administration of Islamic Religion of the States. For example, section 32 (1) of the Administration of Islamic Law (Federal Territories) Act [Act 505] (1993) provides that the Yang Dipertuan Agong may, on the advice of the Minister and after consultation with the Federal Territory Islamic Religious Council (MAIWP), appoint qualified and suitable persons to be Mufti and Deputy Mufti of the Federal Territories". Additionally, the fatwa administration and management at the state level is governed by the Mufti Department responsible for executing tasks enacted by the State Islamic Religious Council as a religious authority.

Hence, this article mainly discusses the position of fatwa as a legal instrument in Malaysia with a focus on its status within the context of the Federal Constitution, 
State and Civil Islamic Law, and other acts enacted by the Government. Accordingly, this paper seeks to answer whether fatwa is constitutional or merely an opinion of Muftis without legal basis.

This explanation will impact the understanding of the relevance of the fatwa institution as the highest source of Islamic law in explaining the views of law and recognized in the legal system in Malaysia.

\section{MATERIAL AND METHOD}

\section{Document Analysis}

Document analysis is used as a research method to answer whether the fatwa is considered constitutional under the principles of federalism. Apart from that, it is also to find the position of fatwa in Shariah and civil law practiced in Malaysia. This method examines several statutes related to fatwas and legislation to see how closely they are related.

Document analysis is sometimes explained as content analysis that is often used through a systematic examination of records and documents. As for this study, documents either in handwriting or printed form such as books or recorded materials that report or record an event or matter are among the documents to be analyzed in this study (Long, 2009). The document analysis comes from two data sources: primary source such as the Federal Constitution and provisions of laws implemented at the state level like Statutes of Administration of Islamic Religion of the States and secondary sources such as journal articles, seminars and conferences papers. Similarly, documents related to fatwas from the historical context and its development and other issues are written and printed. Additionally, documentation on the institution and management of fatwas in Malaysia in terms of its position in the legal system in Malaysia is mentioned in Statutes of Administration of Islamic Religion of the States and act/enactments/ordinances of the states that will also be taken as reference. Therefore, each data collection in this study is based on two sources of documents, namely primer or primary data and secondary or supporting data.

Among the sources of documentation used for this study are scriptures either in Arabic or English, which are considered a major source of discourse on the position of fatwa in Malaysia. In addition, Islamic legal books that discuss legal issues and fatwas issued by local and foreign writers are also considered as a primary reference in this work.

Similarly, the documents that are the source of legislation and judgment, such as the Federal Constitution, related statutes, are also the primary reference to support the source of fatwa authority in court. Thus, the source includes the State Islamic Religious Administration Act, Enactments and Ordinances, State Criminal Offenses Act, Enactments and Ordinances, and other related statutes. Also, several other acts such as the Evidence Act and Syariah Courts Act.

\section{DATA ANALYSIS PROCEDURES}

The data analysis process of this research begins with the data collection process 
in document form. The procedure of data collection and analysis goes together with the techniques introduced by Merriam (2009). Moreover, the procedure is carried out continuously to ensure a smooth flow of data collection and analysis processes for a systematic data organization. It is based on the view of Bogdan and Biklen (1992) and Iksan (2011).

For data analysis and review purposes, the researcher uses the necessary methods that are useful for this research, namely:

\section{Text Analysis}

This method is used to analyze data in the form of texts related to the background, history, development, role, and function of fatwa institutions in the history of Islamic law, especially in terms of its position in the Constitution as well as Shariah and civil law practice in Malaysia.

\section{Descriptive Method}

The data obtained from this study are primary and secondary data presented in descriptive form; to study the extent to which this fatwa is constitutional, which certainly refers to the sources of the Constitution, State Islamic law, and some provisions of the relevant enactments and acts.

\section{Thematic Method}

For this study, the researcher uses thematic methods by examining the themes identified from data findings. As a result, several key themes have been formed that reflect the overall study findings. Major themes that are salient in this study are to be presented as follow:

1. Fatwa is something that is deemed constitutional based on the Federal Constitution

2. Fatwa in Malaysia is considered authoritative and complies with the concept of federalism practiced in Malaysia through the division of jurisdiction at the federal and state levels

3. Fatwa is recognized based on the State Islamic and civil law practiced in Malaysia.

4. Fatwas that have legislative power are fatwas gazetted at the state level.

\section{FATWA IN THE CONSTITUTION AND CONCEPT OF FEDERALISM}

Based on the federalism concept on the distribution of powers as practiced in Malaysia, the administration of Islam that includes fatwa matters falls under the jurisdiction of the state. Therefore, it is provided in Item 1, State List, Ninth Schedule, and Federal Constitution:

"Except with respect to the Federal Territories of Kuala Lumpur and Labuan, Islamic law and personal and family law of persons professing the religion of Islam, including the Islamic law relating to succession, testate and intestate, betrothal, marriage, divorce, dower, maintenance, adoption, legitimacy guardianship, gifts, partitions and non- charitable 
trusts; Wakafs and the definition and regulation of charitable and religious endowments, institutions, trusts, charities and charitable institutions operating wholly within the state; Malay customs. Zakat, Fitrah and Baitulmal or similar Islamic religious revenue, mosques or any Islamic public places of worship, creation and punishment of offences by persons professing the religion of Islam against precepts of that religion, except in regard to matters included in the Federal List; the constitution, organization and procedure of Syariah courts, which shall have jurisdiction only over person professing the religion of Islam and in respect only of any of the matters included in this paragraph, but shall not have jurisdiction in respect of offences except in so fat as conferred by federal law*, the control of propagating doctrines and beliefs among persons professing the religion of Islam; the determination of matters of Islamic law and doctrine Malay custom." (Federal Constitution, 2006).

The Federal Constitution does not entirely deny state power over Islamic law and administration. However, states are still bound by the provisions contained in the Constitution. Any Islamic law enacted by the state should not be contrary to the Federal Constitution, which is the supreme law of the land (Majid, 1997). Therefore, matters related to Islamic law cannot be implemented except through laws enacted by the State Legislative body. It should be read together with Article 74 (2), which provides:

"Without prejudice to any power to make laws conferred on it by any other Article, the Legislature of a State may make laws with respect to any of the matters enumerated in the State List (that is to say, the Second List set out in the Ninth Schedule) or the Concurrent List." (Federal Constitution, 2006)

The articles mentioned above imply that any discussion on fatwa and its institutions need to refer to provisions contained in the Federal Constitution and State Law to ensure its authority as a source of Islamic law of the country. The issue here is the term 'fatwa' that is not being mentioned literally in the provisions of the Constitution. Thus, to what extent does the Constitution authorize the Islamic institutions involved in the issuance of fatwa? This matter needs to be understood in the context of the Constitution, which also provides for the position of Islam as mentioned in Articles 3, 11, 12 (2), and 150 (6A). These provisions may directly or indirectly affect the realization of Islam (Bari, 2005).

The Constitution also authorizes the Parliament to come up with laws related to Islamic affairs. Article 76 (1) of the Federal Constitution addressed the power of Parliament to enact laws for states in some issues, including laws to promote the 
uniformity of law between two or more states. Similarly, if requested by any State Legislative Assembly, the Parliament has to make law, including Islamic-related laws. However, the federal power must be exercised at the request or permission of the state (Federal Constitution, 2006).

The Constitution also distributes power to the state through the State Legislative Assembly to enact laws, including those related to the administration of fatwas to be part of the law being enforced. Thus, once the gazetted fatwa is violated, legal action can be imposed on the parties involved. This provision indicates that laws relating to violations of fatwa are among the rights of the state. It follows from the provisions of the Constitution, which make it clear that a law cannot be enacted in a state until it has been adopted as law by the State Legislature concerned. The validity of fatwa, which is part of the State law, is based on the provisions of this Constitution. On this basis, Shariah-related laws were enacted at the state level to ensure that matters on Islamic administration are governed under the provisions of the Constitution.

Several other provisions, as in Articles 11 (3), 12 (2), 150 (6A), and the Fourth Schedule of Article 37, can also be used to justify fatwas as the source of Islamic law in Malaysia. Therefore, it must be read together with Article 74 (2) and Item 1, State List, Ninth Schedule, Federal Constitution.

Articles 11 (3) and 12 (2) of the Federal Constitution provide that each religious group is independent and has the right to manage its religious affairs (Federal Constitution, 2006). Based on this provision, the Constitution has authorized the establishment or maintenance of Islamic institutions. The state can provide financial assistance to establish Islamic institutions and teach Islam to Muslims (Abas, 2006; Aziz, 2015). Islamic institutions are responsible for administering matters related to the fatwa. The establishment of fatwa institutions and the distribution of financial allocations to these institutions do not conflict with the Constitution. Establishing a fatwa institution at the national or state level is one way to create authoritative management and administrative system in fatwa-related matters. Apart from that, the fatwa institution is intended to develop new Islamic laws and fatwas as a guide to the society and reference the formulation of government policies on religious issues. Not only that, but the fatwa institution also serves to assist the judicial institutions in resolving disputes.

In Article 150 (6A), the Federal Constitution provides for six rights that cannot be violated even if the country is in an emergency, among them are those related to Islamic law, including Administration of Islamic Law (Bari, 2005; Federal Constitution, 2006; Halim, 2013). This provision also strongly justifies the position of fatwa as part of Islamic law. Hence the fatwa and Islamic law implemented in Malaysia can be considered a form of protected, high-ranked and unchallenged through means that are considered unconstitutional. Therefore, the Islamic law includes the enacted fatwa as part of Islamic law, which cannot be revoked even in the case of an emergency. 
Also supporting the position of fatwa as constitutional refers to the Fourth Schedule of Article 37 of the Federal Constitution as cited from the oath made by Yang Dipertuan Agong during the day of his coronation:

“...Further we do solemnly and truly declare that we shall at all time protect the religion of Islam and uphold the rules of law and order in the Nation...." (Federal Constitution, 2006).

This provision can be explained and interpreted as upholding, preserving, and protecting Islamic institutions (Halim, 2013). According to Bari (2005), although the Yang Dipertuan Agong is not positioned as the religious leader for the entire Federation, he has the role and responsibility to ensure that the position of Islam is well preserved and honored. This role also refers to the fatwa institution protected by the Yang Dipertuan Agong and the Malay Rulers. The establishment of the fatwa institution is mainly to advise the Yang Dipertuan Agong and the Malay Rulers on matters pertaining to Islamic affairs. Therefore, the provision mentioned above is an explicit declaration of the Yang Dipertuan Agong's responsibility to defend and uphold Islam as the Federal Religion. Although the word fatwa is not mentioned, the confession of preserving Islam includes protecting the fatwa institution from being interfered with by any devious parties.

Article 38 of the Constitution also provides for the role of the Conference of Rulers, among others: (b) agreeing or disagreeing to the extension of any religious acts, observances or ceremonies to the Federation as a whole;

(c) consenting or withholding consent to any law and making or giving advice on any appointment which under this Constitution requires the consent of the Conference, or is to be made by or after consultation with the Conference.

What is the relationship between the Conference of Rule and the fatwa institution as a constitutional body, and protected by law? On 17 October 1968, the 81 st Conference of the Conference of Rulers of Malaysia agreed that a coordinating body for matters relating to Islamic affairs in Malaysia should be established. This agreement led to the official establishment of the National Council for Islamic Religious Affairs Malaysia (MKI) on 1 of July 1969. The duties of the MKI are:

1) to discuss, deliberate, and manage any issues referred to the Council by the Majlis Raja-Raja, any State Government or State Islamic Religious Council or member of the Council, to provide advice or recommendation.

2) providing advice to the Majlis Raja-Raja, State Government, or State Islamic Religious Council on any matter relating to Islamic Law or the administration of Islamic Law and Islamic education to improve, coordinate or encourage standardization in law or administration. 
With reference to the Constitution's provisions, the Fatwa Committee, both at the national or state level, was established to impart a thorough understanding of Islamic law to the community. Beginning with a proper setup before the arrival of the British in Malaya, the fatwa institution gradually improved over time to ensure its existence remained relevant as an authoritative source of law. Apart from that, the fatwa institution and Mufti have been recognized as the highest reference in resolving disputes about Islamic law. Their important position in the Constitution is evident, although they are not mentioned in any provision. This argument is solid to rebuff the claim that the fatwa institution is unconstitutional and has no legal power.

\section{FATWA IN STATE ISLAMIC LAW}

Fatwa Malaysia is administered through Acts, Enactments, and Ordinances under the Islamic Religious Administration of the States. As Ibrahim (1999) explained, the Islamic Religious Council and officials such as the Mufti, Qadhi (syarie judge), and other positions were created to play a role in the governance of the law. The Mufti, who is usually the Chairman of the Fatwa Committee, is responsible and given the task of issuing fatwas. The rules of fatwa administration are established to ensure that the fatwa institution is well managed and compliant with the law. Thus, the fatwa management is seen as regulatory and constitutional. The Mufti can only be issued a fatwa through the legal process with members of the Fatwa Committee.
This process also involves the State Islamic Religious Council and consent from the Sultan before it is gazetted as a fatwa. This procedure avoids any release of a fatwa by those without the authority, particularly when it comes to legal views on major issues that involve national interests (Ismail, 2014; Husin, 2012; Shuaib, 2009).

The procedures mentioned above explain that fatwa practice in Malaysia does have its legal effect owing to statutes and legal provisions in the Acts, Enactments, and Ordinances of the Islamic Religious Administration of the States and State Enactments related to fatwas. Similarly, muftis are part of the law that must be complied with. Should there be any violation or opinion that contradicts the gazetted fatwa, it is considered an offense and can be prosecuted.

Up to December 2021, two states have enacted fatwa laws exclusively. The Mufti and Fatwa (Kedah Darul Aman) Enactment 2008 and the Fatwa Enactment (Sabah) 2004. Compared to other states, provisions related to fatwas are only included in the Islamic Administration Act, Enactment, and Ordinance in their respective states.

Laws related to fatwas are also found in Acts, Enactments, and Ordinances under the Shariah Crimes of the States, which involve various offenses, namely:

1) False Doctrine (s. 4 Syariah Criminal Offences Act (Federal Territories) [Act559] 1997, s. 4 Syariah Criminal Offences Enactment (Johor) 1997; s. 4 Syariah Criminal Offences Ordinance (Sarawak) 2001; s. 7 Syariah Criminal Offences 
Enactment (Selangor) 1995; s. 4 Syariah Criminal Offences Enactment (Takzir) (Terengganu) 2001; s. 5 Syariah Criminal Offences Enactment (Pahang) 2013; s. 4 Syariah Criminal Offences Enactment (State of Penang) 1996; s. 52 Syariah Criminal Offences (Sabah) Enactment 1995 and s. 4 Syariah Criminal Offences (Kedah Darul Aman) Enactment 2014.

2) Contempt or defiance of religious authorities (s. 9 Syariah Criminal Offences Act (Federal Territories) [Act559] 1997; s. 9 Syariah Criminal Offences Enactment (State of Penang) 1996; s. 65 Enakmen Kesalahan Syariah (Melaka) 1991; s. 50 Syariah Criminal Enactment (Negeri Sembilan) 1992; s. 9 Syariah Criminal Offences Ordinance (Sarawak) 2001; s. 9 Syariah Criminal Offences Enactment (Johor) 1997; s. 12 Syariah Criminal Offences Enactment (Selangor) 1995; s. 10 Syariah Criminal Offences Enactment (Takzir) (Terengganu) 2001; s. 14 Crimes Syariah Enactment (Perak) 1992; s. 56 Syariah Criminal Offences Enactment (Sabah) 1995; s. 38 Criminal Offences in the Syarak Enactment (Perlis) 1991 and s.9 Syariah Criminal Offences (Kedah Darul Aman) Enactment 2014. Meanwhile, in s. 13 Syariah Criminal Offences Enactment (Pahang) 2013 and s. 32 Syariah
Criminal Code (Kelantan) 1985; it is included in disobeying the Sultan/ Raja order due to the offense of not complying with the order through a notification in the Gazette.

3) Insulting, or bringing into contempt, etc., the religion of Islam. This offense involves ridiculing or causing contempt for any law in force, including fatwas related to Islam. It is allocated in the s. 7 Syariah Criminal Offences Act (Federal Territories) [Act559] 1997; s. 7 Syariah Criminal Offences Enactment (Johor) 1997; s. 7 Syariah Criminal Offences Ordinance (Sarawak) 2001; s. 10 Syariah Criminal Offences Enactment (Selangor) 1995; s. 8 Syariah Criminal Offences Enactment (Takzir) (Terengganu) 2001; s. 11 Syariah Criminal Offences Enactment (Pahang) 2013; s. 7 Syariah Criminal Offences Enactment (State of Penang) 1996; s. 14 Crimes Syariah Enactment (Perak) 1992; s. 53, 54 \& 55 Syariah Criminal Offences Enactment (Sabah) 1995 and s. 7 Syariah Criminal Offences (Kedah Darul Aman) Enactment 2014. In s. 62 and s. 63 Enakmen Kesalahan Syariah (Melaka) 1991, it was placed under the offense of insulting Islam, while in s. 39 Criminal Offences in the Syarak Enactment (Perlis) 1991, convicted of insulting Islam and fatwas. 
4) Opinion contrary to the fatwa. It is allocated in the s. 12 Syariah Criminal Offences Act (Federal Territories) [Act559] 1997; s. 12 Syariah Criminal Offences Enactment (Johor) 1997; s. 12 Syariah Criminal Offences Ordinance (Sarawak) 2001; s. 13 Syariah Criminal Offences Enactment (Selangor) 1995; s. 12 Syariah Criminal Offences (Takzir) (Terengganu) Enactment 2001; s. 15 Syariah Criminal Offences (Pahang) Enactment 2013; s. 12 Syariah Criminal Offences (State of Penang) Enactment 1996; s. 21 Crimes Syariah Enactment (Perak) 1992 and s. 9 Syariah Criminal Offences (Kedah Darul Aman) Enactment 2014. In s. 47 Enakmen Kesalahan Syariah (Melaka) 1991; s. 51 Syariah Criminal Enactment (Negeri Sembilan) 1992; s. 50 Syariah Criminal Offences Enactment (Sabah) 1995) addresses this offense under the section of the invalid or unlawful fatwa that contradicts any fatwa issued by the Mufti and which has been gazetted. While in s. 35 Criminal Offences in the Syarak Enactment (Perlis) 1991 is the official fatwa related to Islamic law.

5) Offense related to religious publication contrary to Islamic Law/ hukum syara'. All states have this provision except for Kelantan. It allocated in s. 13 Syariah Criminal Offences Act
(Federal Territories) [Act559] 1997; s. 16 Syariah Criminal Offences Enactment (Selangor) 1995; s. 54 Syariah Criminal Enactment (Negeri Sembilan) 1992; s. 48 Enakmen Kesalahan Syariah (Melaka) 1991; s. 22 Crimes Syariah Enactment (Perak) 1992; s. 13 Syariah Criminal Offences Enactment (State of Penang) 1996; s. 36 Criminal Offences in the Syarak Enactment (Perlis) 1991; s. 51 Syariah Criminal Offences Enactment (Sabah) 1995; s. 13 Syariah Criminal Offences Ordinance (Sarawak) 2001; s. 17 Syariah Criminal Offences Enactment (Pahang) 2013; s. 14 Syariah Criminal Offences Enactment (Takzir) (Terengganu) 2001; s. 13 Syariah Criminal Offences Enactment (Johor) 1997) and s. 12 Syariah Criminal Offences (Kedah Darul Aman) Enactment 2014.

6) Terengganu is the only state that provides the "Issuing fatwas" section, which prohibits anyone from issuing fatwas on Islam or Islamic law either orally or written except for the Mufti or the Fatwa Committee (s. 13 Syariah Criminal Offences Enactment (Takzir) (Terengganu) 2001). This provision is not available in the Acts, Enactments, and Ordinances under Criminal Offenses of other States. 
From the point of view of Islamic law and its implementation in the state, the fatwa shows the value of binding (mulzim) to the Muslims who gazette the fatwa. This provision is found in the Acts, Enactments, and Ordinances of the Islamic Religious Administration of the states. For example, Section 34 of the Administration of Islamic Law (Federal Territories) [Act505] 1993 provides:

(3) When published in the Gazette, a fatwa shall be binding on every Muslim residing in the Federal Territories as his religious teachings. It shall be his religious obligation to comply with and adhere to the fatwa unless Hukum Syarak permits him not to follow the fatwa is in matters of practice, belief, or personal opinion.

\section{FATWA IN CIVIL LAW}

Apart from the Federal Constitution, several other civil laws can justify that the establishment of fatwa and its institutions are valid based on the legal system practiced in the country. Section 45, Evidence Act (1950) provides for expert evidence that the court can, when necessary, obtain an opinion or matter from those who are skilled in a particular field of specialization (Evidence Act, 1950). Several cases in the civil court involve the views of the Mufti as expert evidence, among them, the case Penang Islamic Religious Council v. Abdul Latiff Hassan (As Administrator of Estates of $\mathrm{Hj}$ Mohammad Hj Abdul Rasid; Deceased) \& Anor (2016); case Linggam Sundarajoo v. Kedah Darulaman State Religious Council
(1994); case Fathul Bari Mat Jahya \& Anor v. Negeri Sembilan Islamic Religious Council \& Ors (2012); case Penang Islamic Religious Council \& Seberang Peraiv. Khatijah Yoan \& ORS (2010).

In the discipline of knowledge related to the Islamic judicial system, the expert's testimony is called ra'y al-khabir, which means the testimony of a skilled person in a field. Zaydan (1995) refers to them as ahl al-khibrah, i.e., those who are experts or experienced, i.e., experts chosen by judges from among those who are fair, trustworthy, and experienced in judicial matters that require their expertise in convicting and strengthening something. At the same time, al-Damm (1982) stated that the judge might ask for scholars of the two disputed parties present at the trial or judgment to discuss and present views on the issues in dispute or discuss the dispute. However, the judge should not imitate the views of the socalled scholars because the judge should be more precise in deciding the law based on evidence. Therefore, the scholars' view as skilled persons is just a process of ijtihad to help the judge make decisions.

The court can seek the opinion of those who are members or experts based on specialized knowledge in a field to help him decide a case under trial (Othman, 2003). A court judge should do this action to seek an expert's opinion in a field to assist him in upholding justice. However, judges should always be careful in accepting advice and opinions from others, even if it comes from an expert. In matters related to Islamic law, the muftis are among those 
who are categorized as experts, and their views can only be consulted in resolving disputes that occur either in the Syariah or civil courts. This Act can be considered an added value in strengthening the position of fatwa institutions that have a legal basis in Malaysia. The Syariah Court Evidence (Federal Territories) [Act 561] (1997) provides for taking of evidence or opinion of experts in dispute cases in the Shariah court. It is included as one of the means of proof as found in Sections 33 (1) (2) and (3) and section 34 of the Act:

Section 33. Opinion of experts.

(1) When the Court has to form an opinion upon a point of foreign law or science or art, or as to identity or genuineness of handwriting or finger impressions or relating to the determination of nasab, the opinions upon that point of persons specially skilled in that foreign law, science or art, or in questions as to identity or genuineness of handwriting or finger impressions or relating to the determination of nasab, are qarinah.

(2) Such persons are called experts.

(3) Two or more experts shall be called to give evidence where possible, but if two experts are not available, the evidence of one expert is sufficient. If two experts give different opinions, a third expert shall be called to give evidence.

Section 34. Facts bearing upon opinions of experts.

Facts not otherwise qarinah are qarinah if they support or are inconsistent with the experts' opinions when such opinions are qarinah.

The question is, can the views and opinions of the Mufti have considered as expert evidence? While it may be true that it is rather difficult to confirm this view, the State Islamic Religious Administration Act, Enactments and Ordinances provide that Mufti's testimony can be accepted in court. Moreover, it can be assumed that Mufti's opinion will be accepted because of his capacity as a legal expert in Islamic law. Therefore, taking everything into account, the provisions in the Evidence Act (1950) do include the testimony of the Mufti as an expert in matters related to Islam.

\section{LIST OF FATWA RELATED CASES IN MALAYSIAN COURTS}

The lists of cases related to a fatwa, whether they are references or not in the Syariah and civil courts, have been analyzed at length in the article discussing fatwa authority and the opinion of the Mufti in Shariah and civil law court in Malaysia (Mat Salleh \& Samuri 2016, 2018). The following are some of the cases related to fatwas referred by courts in Malaysia as in Table 1.

\section{RESULTS AND DISCUSSION}

\section{Authority of Fatwa in the Constitution and State of Islamic Law}

Some of the pivotal points supporting the validity of fatwas in the Malaysian legal system refer to the background of the Malaysian Constitution and the State Islamic law. Both of these sources are important to justify and discuss the position of fatwa and 
Table 1

List of fatwa-related cases in Malaysian courts

\begin{tabular}{|c|c|}
\hline \multicolumn{2}{|r|}{ Fatwa and Opinion of the Mufti as a Reference in the Shariah Court } \\
\hline NO. & CASE NAME AND YEAR \\
\hline 1 & Mohd Faizol bin Zainal v. Suhaila bt Yusoff (2014) \\
\hline 2 & Najim Alden Mohammad Saide v. Nadiah Abdul Aziz (2013) \\
\hline 3 & $\begin{array}{l}\text { Tengku Zainul Akmal bin Tengku Besar Mahmud \& Anor v. Islamic Religious and Malay Customs of } \\
\text { Terengganu \& Anor (2012) }\end{array}$ \\
\hline 4 & Norhairy Cheong Abdullah@ Cheong Foo Siong (2010) \\
\hline 5 & Wan Shahriman Wan Suleiman \& Anor v. Siti Norhayati Mohd Daud (2010) \\
\hline 6 & Halijah Abdul Rahman v. Zambree Baharom (2009) \\
\hline 7 & Noridah bt Ab Talib v. Hishamuddin bin Jamaluddin (2009) \\
\hline 8 & Wan Ismail Wan Endut v. Wan Puziah Wan Awang (2007) \\
\hline 9 & Bakhtiar Adnan v. Mohd Fawzi Nahrawi \& others (2006) \\
\hline \multicolumn{2}{|r|}{ Fatwa and Opinion of the Mufti Not as a Reference in the Shariah Court } \\
\hline NO. & CASE NAME AND YEAR \\
\hline 1 & Faizal bin Rabion v. Nurul Fazila bt Nawi (2014) \\
\hline 2 & Zafrin Zulhilmi bin Pauzi v. Noor Aini bt Nasron (2013) \\
\hline 3 & Nor Aniza bte Idris v. Mohammad Fauzi bin Ahmad (2006) \\
\hline 4 & Che Mas Abdullah v. Mat Sharie Yaakub (2005) \\
\hline \multicolumn{2}{|r|}{ Fatwa and Opinion of the Mufti as a Reference in the Civil Court } \\
\hline NO. & CASE NAME AND YEAR \\
\hline 1 & $\begin{array}{l}\text { Penang Islamic Religious Council v. Abdul Latiff Hassan (As Administrator of Estates of Hj } \\
\text { Mohammad Hj Abdul Rasid; Deceased) \& Anor (2016) }\end{array}$ \\
\hline 2 & Ahmad Yahaya v. Penang Islamic Religious Council (2015) \\
\hline 3 & Ikbal bin Salam v. Malay Johore Cooperative Credit \& Investment Society \& Anor (2012) \\
\hline 4 & Penang Islamic Religious Council \& Seberang Perai v. Khatijah Yoan \& ORS (2010) \\
\hline 5 & Re Bentara Luar, Deceased, Hj. Yahya bin Yusoff and others v. Hassan bin Othman and others (1981) \\
\hline 6 & Linggam Sundarajoo v. Kedah Darulaman State Religious Council (1994) \\
\hline 7 & Dalip Kaur v. Police Officer, Bukit Mertajam $(1991,1992)$ \\
\hline 8 & Viswalingam v. Viswalingam (1980) \\
\hline 9 & Re Estate Sheikh Mohamad bin Abdul Rahman bin Hazim (1974) \\
\hline 10 & NorA’shedah Jamaluddin@ Yusor \& Anorv.Datuk Zainul Arifin Mohammed Isa \& Anor (2012) \\
\hline 11 & Fathul Bari Mat Jahya \& Anor v. Negeri Sembilan Islamic Religious Council \& Ors (2012) \\
\hline 12 & Hjh Halimatussaadiah bte Hj Kamaruddin v. Public Services Commission, Malaysia \& Anor (1994) \\
\hline \multicolumn{2}{|r|}{ Fatwa and Opinion of the Mufti Not as a Reference in Civil Courts } \\
\hline NO. & CASE NAME AND YEAR \\
\hline 1 & Isa Abdul Rahman and others v. Penang Islamic Religious Council (1996) \\
\hline 2 & G Rethinasamy v. Penang Islamic Religious Council and others (1993) \\
\hline 3 & Commissioner of Religous Affairs, Terengganu and others v. Tengku Mariam (1969) \\
\hline 4 & Victoria Jayaseele Martin v. Federal Territory Islamic Religious Council \& Anor (2001) \& (2011) \\
\hline 5 & Titular Chief Priest of Roman Catholic Kuala Lumpur v. Minister of Home Affairs \& Anor (2010) \\
\hline
\end{tabular}

Note: This table refers to court cases obtained through Malayan Law Journal (MLJ) Current Law Journal (CLJ) and Shariah Law Reports (ShLR). 
the opinion of Mufti as an authoritative legal source. The study findings determine that the Federal Constitution and State Islamic Law recognize the position of fatwas as a source of Islamic law in Malaysia. This recognition is based on the involvement of state religious authorities, including Raja and Sultan, the Office of Legal Advisers, and the State Islamic Religious Council in strengthening the legitimacy of this fatwa institution.

Hence, the existence of fatwa institutions both at the state and national levels is considered constitutional as mentioned in Article 1 of List 2, Schedule 9 of the Federal Constitution that provides for the jurisdiction of Islamic law under the jurisdiction of the State (Federal Constitution, 2006). Similarly, the role of the Yang Dipertuan Agong and the Council of Rulers (Majlis Raja-Raja) as the patron saint of religion at the Federal and state levels proves that the fatwa institution is constitutional and recognized. Furthermore, the power of the Council of Rulers opens the door to the existence National Council for
Islamic Religious Affairs Malaysia (MKI), national and state level fatwa institutions.

The division of powers at the federal and state levels through the concept of federalism, which is modeled on the Federal Constitution, is a strong backbone that enable the fatwa institution to be lawfully administered. It involves various matters related to the management, administration of fatwas, gazetting, coordination, standardization and enforcement of fatwas. All this is legal because the Constitution protects it.

The position of fatwa as an authoritative source of legislation is illustrated through the diagram below as in Figure 1.

On a final note, the Mufti and fatwa are both constitutional when it comes to their existence. Reference to the supreme law in Malaysia gives the right to the State Government to administer matters related to fatwa matters. The Yang Dipertuan Agong and the Council of Rulers as the religious patron are institutions that protect the existence of the fatwa institution as the most authoritative body and source of

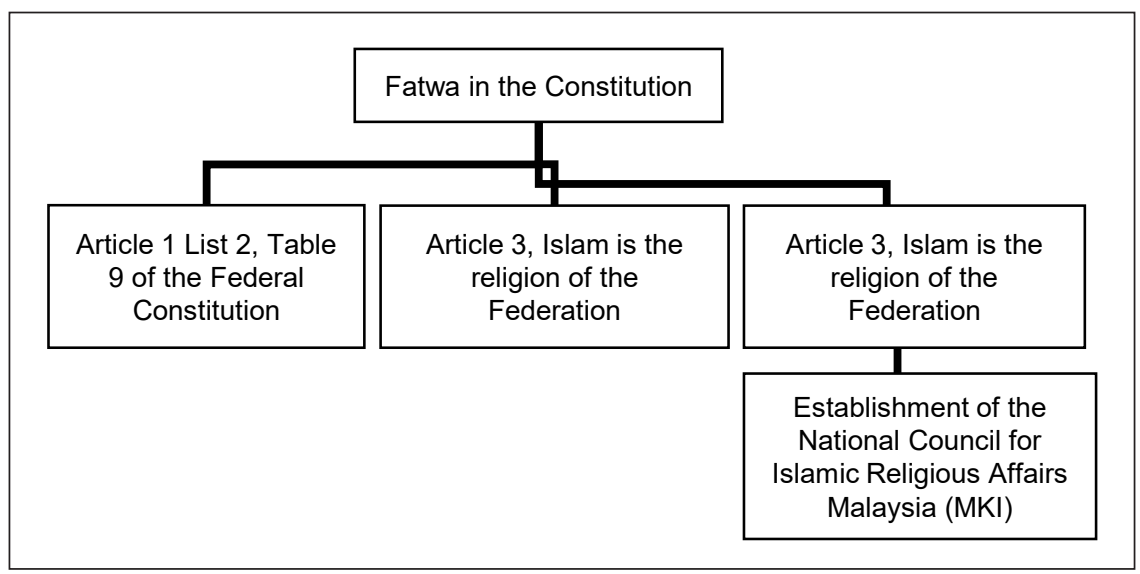

Figure 1. Position of fatwa as an authoritative legal source 
legal reference in Malaysia. Meanwhile, the National Council for Islamic Religious Affairs Malaysia (MKI) and fatwa institutions at the state level are solid evidence that the Federal Constitution gives privileges to Islamic organizations to manage the administration of matters related to religion and Islamic law. The recognition of their authority also expands in civil law, thus making this fatwa institution valid and legal constitutionally. The existence of several provisions in the State Islamic law related to fatwas also shows that a fatwa is constitutional and is part of the law.

\section{ACKNOWLEDGEMENT}

The authors declare no potential conflict of interest for this article's research, authorship, and publication. The authors also acknowledge Universiti Teknologi MARA (UiTM) and Universiti Kebangsaan Malaysia (UKM) for their appreciation and support in the publication of this article.

\section{REFERENCES}

Abas, M. S. (2006). Prinsip perlembagaan dan pemerintahan di Malaysia [Principles of constitution and governance in Malaysia]. Dawama Sdn. Bhd.

Administration of Islamic Law (Federal Territories) Act 1993 [Act 505] s. 32(1) and s. 34 (Malaysia) (1993).

Ahmad Yahaya v. Penang Islamic Religious Council, 1 LNS 802 (2015).

al-Damm, I. A. S. a.-D A. I. I. I. A. A. (1982). Kitab adab al-qada' aw al-durar al-manzumat fi alaqdiah wa al-hukumat [The book of judges ethics or the pearls of the systems in judgements and rulings]. In M. M. al-Zuhayli (Ed.). Dar al-Fikr.

Aziz, S. A. (2015). Institusi fatwa dalam perundangan negara [Fatwa institutions in national legislation]. Malaysian Institute of Islamic Understanding (IKIM).

Bakhtiar Adnan v. Mohd Fawzi Nahrawi \& others, 1 CLJ (SYA) 316 (2006).

Bari, A. A. (2005). Islam dalam Perlembagaan Malaysia [Islam in the Malaysian Constitution]. Intel Multimedia and Publication.

Bogdan, R. C., \& Biklen, S. K. (1992). Qualitative research for educations: An introduction to theories and methods. Pearson Education Group Inc.

Che Mas Abdullah v. Mat Sharie Yaakub, 2 (SYA) 1 (2005).

Commissioner of Religous Affairs, Terengganu and others v. Tengku Mariam, 1 MLJ 110 (1969).

Crimes Syariah Enactment (Perak) 1992 s. 14, s. 21 and s. 22 (Malaysia).

Criminal Offences in the Syarak Enactment (Perlis) 1991 s. 35, s. 36, s. 38 and s. 39 (Malaysia).

Dalip Kaur v. Police Officer, Bukit Mertajam, 1 MLJ 1 (1992).

Dalip Kaur v. Police Officer, Bukit Mertajam, CLJ Rep 77 (1991).

Department of Islamic Development Malaysia. (2013). Peraturan Majlis Kebangsaan Bagi Hal Ehwal Ugama Islam Malaysia [Regulations of the National Council for Islamic Religious Affairs of Malaysia]. JAKIM.

Department of Islamic Development Malaysia. (2018). Results of the Muzakarah of the Fatwa Committee of the National Council for Islamic Religious Affairs Malaysia. JAKIM. 
Enakmen Kesalahan Syariah (Melaka) 1991 s. 47, s. 48, s. 62 , s. 63 and s. 65 (Malaysia).

Evidence Act 1950 s.45 (Malaysia).

Faizal bin Rabion v. Nurul Fazila bt Nawi, 1 ShLR 137 (2014).

Fathul Bari Mat Jahya \& Anor v. Negeri Sembilan Islamic Religious Council \& Ors, 4 CLJ 717 (2012).

Fatwa Enactment (Sabah) 2004.

Federal Constitution (2006).

G Rethinasamy v. Penang Islamic Religious Council and others, 2 MLJ 166 (1993).

Halijah Abdul Rahman v. Zambree Baharom, 1 CLJ (SYA) 402 (2009).

Halim, A. F. A. (2013, Januari 8). Memartabatkan Islam sebagai agama negara. [Dignifying Islam as the national religion]. https:// muafakatmalaysia.wordpress.com/2013/01/08/ tun-fairuz-memartabatkan-islam-sebagai-agamanegara/

Hjh Halimatussaadiah bte Hj Kamaruddin v. Public Services Commission, Malaysia \& Anor, 3 MLJ 61 (1994).

Husin, A. S. (2012, April 12). Ke arah penyelarasan Fatwa di Malaysia [Towards the coordination of Fatwas in Malaysia] [Paper Presentation]. Proceedings of the National Seminar on Coordination of Fatwa Enforcement in Malaysia. Universiti Sains Islam Malaysia \& Department of Islamic Development Malaysia, Nilai Negeri Sembilan, Malaysia.

Ibrahim, A. M. M. (1999). Pentadbiran undangundang Islam di Malaysia [Administration of Islamic law in Malaysia]. Malaysian Institute of Islamic Understanding (IKIM).

Ikbal bin Salam v. Malay Johore Cooperative Credit \& Investment Society \& Anor, MLJU 738 (2012).
Iksan, Z. (2011). Amalan penyoalan lisan guru kimia dalam pengajaran dan pembelajaran elektrokimia [The practice of oral questioning of chemistry teachers in the teaching and learning of electrochemistry, PhD thesis]. Universiti Kebangsaan Malaysia.

Isa Abdul Rahman and others v. Penang Islamic Religious Council, 1 CLJ 283 (1996).

Ismail, M. H. (2014, February 4-6). Kesan ketidakseragaman Fatwa: Pandangan dari sudut undang-undang [The impact of Fatwa inequality: A view from a legal perspective, Paper Presentation]. Proceedings of the Fatwa Management, Coordination Workshop by Mufti Department throughout Malaysia. Department of Islamic Development Malaysia (JAKIM), Shah Alam, Selangor, Malaysia.

Linggam Sundarajoo v. Kedah Darulaman State Religious Council, 2 CLJ 494 (1994).

Long, A. S. (2009). Pengenalan metodologi penyelidikan pengajian Islam [Introduction to Islamic studies research methodology] (5th ed.). Universiti Kebangsaan Malaysia.

Majid, M. Z. A. (1997). Pengantar undang-undang Islam di Malaysia [Principles of constitution and governance in Malaysia]. Penerbit Universiti Malaya.

Mat Salleh, M. K., Samuri, M. A. A., \& Kashim M. I. A. M. (2018). Fatwa sebagai rujukan dan autoriti di Mahkamah Sivil Malaysia [Fatwa as reference and authority in the Malaysian Civil Court]. Journal of Fatwa Management and Research, 11(1), 1-25. https://doi.org/10.33102/ jfatwa.vol11no1.5

Mat Salleh, M. K., Samuri, M. A. A., \& Kashim, M. I. A. M. (2016). Kedudukan Fatwa dan pendapat Mufti sebagai autoriti di Mahkamah Syariah Malaysia [Position of Fatwa and opinion of Mufti as authority in Malaysian Syariah Court]. Journal 
of Contemporary Islamic Law, 1(1), 1-25. http:// www.ukm.my/jcil/2016-1-1-article-1/

Merriam, S. B. (2009). Qualitative research: A guide to design and implementation. Jossey-Bass.

Mohd Faizol bin Zainal v. Suhaila bt Yusoff, 2 ShLR 83 (2014).

Mufti and Fatwa (Kedah Darul Aman) Enactment 2008

Najim Alden Mohammad Saide v. Nadiah Abdul Aziz, 1 CLJ (SYA) 124 (2013).

Nor A'shedah Jamaluddin @ Yusor \& Anorv. Datuk Zainul Arifin Mohammed Isa \& Anor, 1 LNS 926 (2012).

Nor Aniza bte Idris v. Mohammad Fauzi bin Ahmad, 3 ShLR (2006).

Norhairy Cheong Abdullah @ Cheong Foo Siong, 3 LNS 15 (2010).

Noridah bt Ab Talib v. Hishamuddin bin Jamaluddin, 4 ShLR 115 (2009).

Othman, M. S. A. (2003). Undang-undang keterangan Islam [Islamic evidence law] (3rd ed.). Dewan Bahasa dan Pustaka.

Penang Islamic Religious Council \& Seberang Perai v. Khatijah Yoan \& ORS, 3 LNS 5 (2010).

Penang Islamic Religious Council v. Abdul Latiff Hassan (As Administrator of Estates of $\mathrm{Hj}$ Mohammad Hj Abdul Rasid; Deceased) \& Anor, 2 CLJ 150 (2016).

Re Bentara Luar, Deceased, Hj. Yahya bin Yusoff and others v. Hassan bin Othman and others, 2 MLJ 352 (1981).

Re Estate Sheikh Mohamad bin Abdul Rahman bin Hazim, 1 MLJ 184 (1974).

Shuaib, F. S. (2009). Pentadbiran dan institusi Islam di Malaysia: Cadangan ke arah pemantapan [Islamic administration and institutions in Malaysia:
Recommendations towards solidification]. Malaysian Law Journal Code, 21(1), 12-28.

Syariah Court Evidence (Federal Territories) Act [Act 561]1997 s. 33(1), (2), (3) and s. 34 (Malaysia).

Syariah Criminal Code (Kelantan) 1985 s. 32 (Malaysia).

Syariah Criminal Enactment (Negeri Sembilan) 1992 s. 50, s. 51, and s. 54 (Malaysia).

Syariah Criminal Offences (Kedah Darul Aman) Enactment 2014 s. 4, s. 9, s. 7 and s. 12 (Malaysia).

Syariah Criminal Offences Act (Federal Territories) [Act559] 1997 s. 4, s. 7, s. 9, s. 12 and s. 13 (Malaysia).

Syariah Criminal Offences Enactment (Johor) $1997 \mathrm{~s}$. 4, s. 7, s. 9, s. 12 and s. 13 (Malaysia).

Syariah Criminal Offences Enactment (Pahang) 2013s. 5, s. 11, s. 13, s. 15 and s. 17 (Malaysia).

Syariah Criminal Offences Enactment (Sabah) 1995 s. 50 , s. 51 , s. 52 , s. 53 , s. 54, s. 55 and s. 56 (Malaysia).

Syariah Criminal Offences Ordinance (Sarawak) 2001 s. 4, s. 7, s. 9, s. 12 and s. 13 (Malaysia).

Syariah Criminal Offences Enactment (Selangor) 1995 s. 7, s. 10, s. 12, s. 13, and s. 16 (Malaysia).

Syariah Criminal Offences Enactment (State of Penang) 1996 s. 4, s. 7, s. 9, s. 12, s. 13 (Malaysia).

Syariah Criminal Offences Enactment (Takzir) (Terengganu) 2001 s. 4, s. 10, s. 8, s. 12, s. 13 and s. 14 (Malaysia).

Tengku Zainul Akmal bin Tengku Besar Mahmud \& Anor v. Islamic Religious and Malay Customs of Terengganu \& Anor, 3 ShLR 39 (2012).

Titular Chief Priest of Roman Catholic Kuala Lumpur v. Minister of Home Affairs \& Anor, 2 CLJ 208 (2010). 
Victoria Jayaseele Martin v. Federal Territory Islamic Religious Council \& Anor, 7 CLJ 233 (2011).

Victoria Jayaseele Martin v. Federal Territory Islamic Religious Council \& Anor, 9 MLJ (2001).

Viswalingam v. Viswalingam, 1 MLJ 10 (1980).

Wan Ismail Wan Endut v. Wan Puziah Wan Awang, 1 CLJ (SYA) 548 (2007).
Wan Shahriman Wan Suleiman \& Anor v. Siti Norhayati Mohd Daud, 1 CLJ (SYA) 85 (2010).

Zafrin Zulhilmi bin Pauzi v. Noor Aini bt Nasron, 2 ShLR 42 (2013).

Zaydan, A. K. (1995). Nizam al-qada'fi al-Shari'ah al-Islamiah [Criminal justice in Islamic judicial procedure in the Shari'a]. Dar al-Bashir. 